

\title{
A novel polymorphism of the myogenin gene is associated with body measurement traits in native Chinese breeds
}

\author{
M. Xue ${ }^{1}$, L.S. Zan ${ }^{1,2}$, L. Gao ${ }^{3}$ and H.B. Wang ${ }^{3}$ \\ ${ }^{1}$ College of Animal Science and Technology, \\ Northwest Agriculture and Forestry University, Yangling, Shaanxi, P.R. China \\ ${ }^{2}$ National Beef Cattle Improvement Centre, \\ Northwest Agriculture and Forestry University, Yangling, Shaanxi, P.R. China \\ Corresponding author: L.S. Zan \\ E-mail: zanls@yahoo.com.cn
}

Genet. Mol. Res. 10 (4): 2721-2728 (2011)

Received December 7, 2011

Accepted July 23, 2011

Published November 4, 2011

DOI http://dx.doi.org/10.4238/2011.November.4.6

\begin{abstract}
Using PCR-SSCP and DNA sequencing technology, we examined the association of single nucleotide polymorphisms (SNPs) in the bovine $M y o G$ gene with body measurement traits in 779 individuals of six native Chinese cattle breeds, namely Luxi, Luxi $\times$ Simmental crossbred, Nanyang, Xia'nan, Jiaxian red, and Qinchuan. A novel SNP, T314C, was detected. Allelic frequencies of $M y o G-\mathrm{T} / \mathrm{C}$ in the six breeds were $0.8308 / 0.1692,0.8774 / 0.1226,0.8021 / 0.1979$, $0.8209 / 0.1791,0.8630 / 0.1370,0.8044 / 0.1956$, respectively. Least squares analysis revealed a significant $(\mathrm{P}<0.05)$ association of the $M y o G$ SNP with rump length in four breeds (Luxi, Xia'nan, Jiaxian red, and Qinchuan), with hucklebone width in three breeds (Luxi $\times$ Simmental crossbred, Nanyang and Xia'nan), with waist height in two breeds (Luxi $\times$ Simmental crossbred and Nanyang) and with body length in the Luxi breed. We conclude that the MyoG SNP has potential as a genetic marker for economically relevant body measurement traits in native Chinese cattle breeds.
\end{abstract}

Key words: Cattle; $M y o G$; Polymorphisms; Body measurement traits 


\section{INTRODUCTION}

Recent research suggests that animals with a higher number of muscle fibers of moderate size produce more meat of better quality (Rehfeldt et al., 2000; te Pas et al., 2000). The number of myofibers in muscles is strictly an embryonic process and is regulated by the $M y o D$ gene family (Olson, 1990). The $M y o D$ family of myogenic regulatory factors ( $M R F s$ ) are specific to muscle and are capable of transforming a variety of cell types into myoblasts (Weintraub et al., 1989).

Members of $M R F s$ include myogenic determination factor $\left(M y o D_{l}\right.$; Davis et al., 1987), myogenin (MyoG; Wright et al., 1989), myogenic factor 5 ( $M Y F_{5}$; Braun et al., 1989), and myogenic factor $6\left(M Y F_{6}\right.$ - also called herculin or $M R F_{4}$; Buckingham et al., 2003).

$M y o G$ has a central position within the $M y o D$ gene family, not only because $M y o G$ expression abrogates myoblast proliferation potential and regulates the differentiation of mononucleated myoblasts into multinucleated myofibers (Wright et al., 1989; Weintraub et al., 1991; Pas and Visscher, 1994), but also due to $M y o G$ being the only member of the $M y o D$ gene family that is expressed in all myogenic cell lines (Anton et al., 2002). The $M y o G$ gene regulates the expression of muscle-specific genes, which encode several proteins that control the formation and apoptosis (or necrosis) of muscle fibers (Olson, 1990; te Pas et al., 1999). On the other hand, it is possible that the $M y o G$ gene is also responsible for determining the number of primary fibers, which may modify the number and type of muscle fibers in the mature animal by controlling embryonic muscle development (Stickland and Handel, 1986). Therefore, the change in the expression profile of the $M y o G$ gene or in its structure, caused by mutations, could influence the process of differentiation and, in the end, muscle characteristics (Wyszynska-Koko et al., 2006). Some authors suggested that the different $M y o G$ genotypes are related to the variation in the number of muscle fibers and growth rate, which lead to a variation in muscle mass (Soumillion et al., 1997; te Pas et al., 1999) and, thus, body measurement.

The bovine $M y o G$ gene is on chromosome 16, along with several QTLs (quantitative trait loci) for carcass weight (Casas et al., 2004). Until now, the association of MyoG genetic variations with body measurement has not been reported in cattle. Therefore, the objective of this study was to detect SNPs in the bovine $M y o G$ gene and to explore their possible association with body measurement traits in native Chinese breeds.

\section{MATERIAL AND METHODS}

\section{Sample collection and DNA isolation}

A total of 779 adult animals at 24-48 months of age were randomly selected from breeding populations, including Qinchuan (QC, $N=473$, Shaanxi Province), Nanyang ( $N Y, N=48$, Henan Province), Jiaxian red (JR, $N=73$, Henan Province), Xia'nan (XN, N = 67, Henan Province), Luxi (LX, N =65, Shandong Province), and Simmental and Luxi crossbred steers (SL, N $=53$, Shandong Province). The following traits were measured as previously described (Gilbert et al., 1993): body length, body height, withers height, rump length, hip height, chest depth, chest circumference, and hucklebone width. In order to minimize systematic error, a single person was assigned to measure one of the five traits in all animals. DNA samples were extracted from leukocytes and tissue samples using a standard phenol-chloroform protocol (Mullenbach et al., 1989). 


\section{PCR amplification and DNA sequencing analysis}

Two primer pairs (Table 1) were designed based on the bovine $M y o G$ gene sequence (GenBank accession No. EF636458) to amplify exon 1 and its flanking regions using the Primer 5.0 software.

\begin{tabular}{|c|c|c|c|c|}
\hline Primer & Sequences & Amplified position & Product size/bp & $\operatorname{Tm}\left({ }^{\circ} \mathrm{C}\right)$ \\
\hline $\mathrm{P}_{0}$ & $\begin{array}{l}\text { F: 5'-TCAGGTTTCTGTGGCGTTGG-3' } \\
\text { R: 5'-CCGGCTGCCTTTGTCTTATCTG-3' }\end{array}$ & Part promoter $+1-705$ & 821 & 67.5 \\
\hline $\mathrm{P}_{1}$ & $\begin{array}{l}\text { F: 5'-GAGGAAGTCGGTGTCTGTGGA-3' } \\
\text { R: 5'-CCCGCTCTATGTACTGGATGG-3' }\end{array}$ & $242-412$ & 173 & 61.5 \\
\hline
\end{tabular}

$\mathrm{Tm}=$ annealing temperature.

Twenty PCR products amplified by the primer $\mathrm{P}_{0}$ were randomly selected for screening for DNA polymorphisms. A $15-\mu \mathrm{L}$ PCR reaction mixture contained $1 \mu \mathrm{L}(50 \mathrm{ng} / \mu \mathrm{L})$ genomic DNA template, $7.5 \mu \mathrm{L} 2 \mathrm{X}$ Taq PCR Master Mix, $5.9 \mu \mathrm{L} \mathrm{ddH}_{2} \mathrm{O}$, and $0.3 \mu \mathrm{L}$ of each primer $(10 \mathrm{M})$. The cycling protocol was $5 \mathrm{~min}$ at $95^{\circ} \mathrm{C}$ (preliminary denaturation), 35 cycles of denaturation at $94^{\circ} \mathrm{C}$ for $30 \mathrm{~s}$, annealing $\left({ }^{\circ} \mathrm{C}\right)$ as indicated in Table 1 for $40 \mathrm{~s}$, and extension at $72^{\circ} \mathrm{C}$ for $40 \mathrm{~s}$, with a final extension at $72^{\circ} \mathrm{C}$ for $10 \mathrm{~min}$. The PCR products were purified with Axygen kits (MBI Fermentas, Canada) and sequenced in both directions using an ABI PRIZM 3730 DNA sequencer (Perkin-Elmer Shanghai Sangon Biological Engineering Technology, Ltd.), and the sequences were analyzed with the BioXM software (version 2.6). Primer $\mathrm{P}_{1}$ was designed, focusing on the mutation site.

\section{PCR-SSCP (single-stranded conformation polymorphism)}

Aliquots of $6 \mu \mathrm{L}$ PCR products were mixed with $10 \mu \mathrm{L}$ denaturing solution (95\% formamide, $25 \mathrm{mM}$ EDTA, $0.025 \%$ xylene-cyanole and $0.025 \%$ bromophenol blue), heated for 10 min at $98^{\circ} \mathrm{C}$ and chilled on ice. Denatured DNA was loaded on a $12 \%$ acrylamide/bisacrylamide (29:1) gel and electrophoresed at $110 \mathrm{~V}$ for $16 \mathrm{~h}$ in $1 \mathrm{X}$ TBE buffer. The gel was then stained with $0.1 \%$ silver nitrate and visualized with $2 \% \mathrm{NaOH}$ solution (supplied with $0.1 \%$ formaldehyde) according to Zhang et al. (2007). The individual genotypes were defined according to the PCRSSCP band patterns that were visualized on the gels with white light (Qu et al., 2005).

\section{Statistical analysis}

The following items were statistically analyzed according to previous approaches (Liu et al., 2010), including genotypic frequencies, allelic frequencies, Hardy-Weinberg equilibrium, and population genetic, indices: $H_{\mathrm{E}}$ (gene heterozygosity), $H_{\mathrm{O}}$ (gene homozygosity), $N_{\mathrm{E}}$ (effective allele numbers) and PIC (polymorphism information content). The association between SNP marker genotypes of the $M y o G$ gene and records of body measurement traits (body length, body height, withers height, rump length, hip height, chest depth, chest circumference, and hucklebone width) were analyzed using the general linear model (GLM) procedure in Statistical Program for Social Sciences (SPSS 17.0, SPSS Inc.), according to the following statistical linear model: 


$$
Y_{i j k}=\mu+A_{i}+G_{j}+S_{k}+E_{i j k},
$$

where $Y_{i j k}$ is the observation for the body measurement trait, $\mu$ is the overall population mean, $A_{i}$ is the fixed effect of the $\mathrm{i}^{\text {th }}$ age, $G_{j}$ is the fixed effect of $\mathrm{j}^{\text {th }}$ genotype, $S_{k}$ is fixed effect of sex, and $E_{i j k}$ is the random error.

\section{RESULTS}

\section{PCR-SSCP analysis of the MyoG gene}

After a 173-bp product of the $M y o G$ gene was amplified (Figure 1), three unique banding patterns were detected by PCR-SSCP analysis. Sequence analysis revealed a T>C mutation, a synonymous mutation of Asn, at position 314 of the $M y o G$ gene (Figure 2). The homozygote, consistent with the sequence of GenBank accession No. EF636458, was called the TT genotype, the other homozygote was called the CC genotype, and the heterozygote was called the TC genotype.

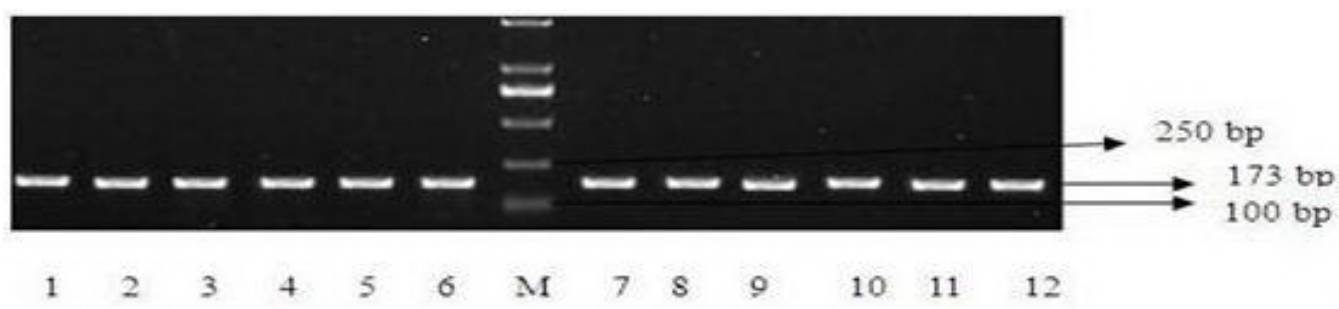

Figure 1. MyoG gene exon 1 PCR amplification products. Lane $M=$ DL2000 Marker; lanes 1-12= PCR products.

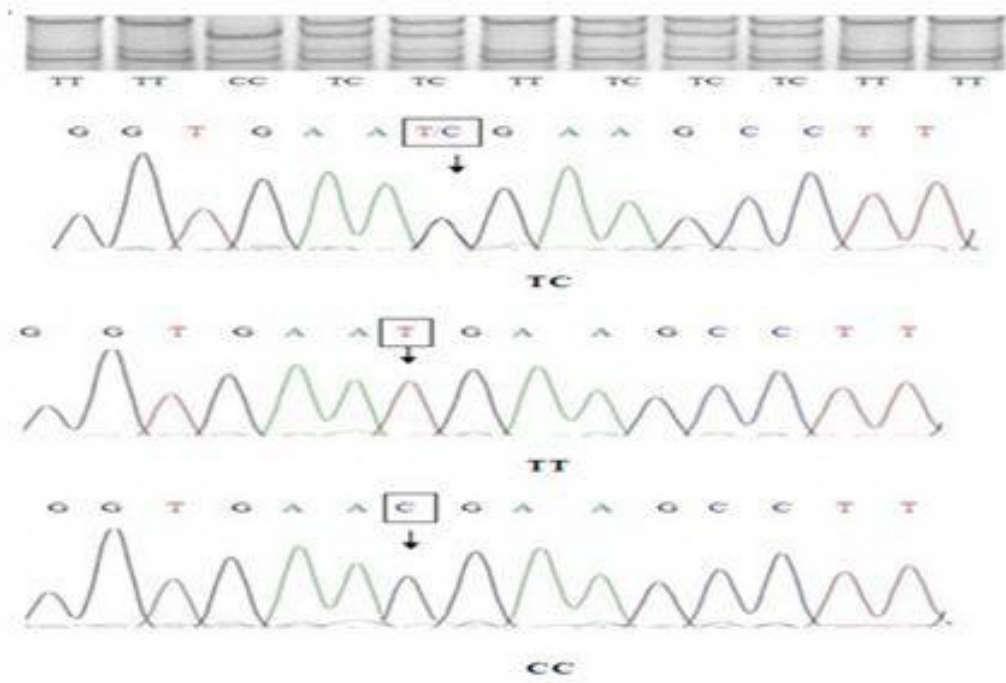

Figure 2. PCR-SSCP patterns and DNA sequencing traces of the bovine $M y o G$ gene locus. Three patterns (TT, TC, CC) were observed in six Chinese indigenous cattle. Sequencing trace revealed a $\mathrm{T}>\mathrm{C}$ mutation at position g.314. 


\section{Genetic polymorphism of the bovine $M y o G$ gene and $\chi^{2}$ test}

Allele frequencies of the SNP were investigated and performed by the $\chi^{2}$ test in all populations of bovine in our study (Table 2). The data shown here demonstrate that allelic frequencies of $M y o G-\mathrm{T} / \mathrm{C}$ in LX, SL, NY, XN, JR, and QC breeds were $0.8308 / 0.1692$, $0.8774 / 0.1226,0.8021 / 0.1979,0.8209 / 0.1791,0.8630 / 0.1370$, and $0.8044 / 0.1956$, respectively. According to the $\chi^{2}$ test, there was a significant difference in allelic frequency between the LX, NY and QC $(\mathrm{P}<0.05)$ populations, suggesting that LX, NY and QC were not in Hardy-Weinberg equilibrium. $H_{\mathrm{E}}, N_{\mathrm{E}}$ and PIC of the bovine $M y o G$ locus in the six native Chinese cattle varied from 0.2152 (SL) to 0.3175 (NY), 1.2742 (SL) to 1.4652 (NY), and 0.1920 (SL) to 0.2671 (NY), respectively (Table 3). Generally, PIC is classified into the following three types: low polymorphism (PIC value $<0.25)$, average polymorphism $(0.25<$ PIC value $<0.5$ ), and high polymorphism (PIC value $<0.5$ ). According to this classification of PIC, the LX, SL and JR breeds belong to the low polymorphism level, while the other breeds belong to the average polymorphism level (Table 3 ).

Table 2. Genotype distribution and allele frequencies of the bovine $M y o G$ gene exon 1.

\begin{tabular}{|c|c|c|c|c|c|c|c|}
\hline \multirow[t]{2}{*}{ Breed } & \multicolumn{3}{|c|}{ Genotype frequencies (number) } & \multirow[t]{2}{*}{ Sample size } & \multicolumn{2}{|c|}{ Allele frequencies } & \multirow[t]{2}{*}{$\chi^{2}(\mathrm{HW})$} \\
\hline & $\mathrm{TT}$ & $\mathrm{TC}$ & $\mathrm{CC}$ & & $\mathrm{T}$ & $\mathrm{C}$ & \\
\hline LX & $0.7385(48)$ & $0.1846(12)$ & $0.0769(5)$ & 65 & 0.8308 & 0.1692 & $7.6666^{*}$ \\
\hline SL & $0.7925(42)$ & $0.1698(9)$ & $0.0377(2)$ & 53 & 0.8774 & 0.1226 & 0.9502 \\
\hline NY & $0.7083(34)$ & $0.1875(9)$ & $0.1042(5)$ & 48 & 0.8021 & 0.1979 & $8.0465^{*}$ \\
\hline $\mathrm{XN}$ & $0.7015(47)$ & $0.2388(16)$ & $0.0597(4)$ & 67 & 0.8209 & 0.1791 & 1.4096 \\
\hline$J R$ & $0.7534(55)$ & $0.2192(16)$ & $0.0274(2)$ & 73 & 0.8630 & 0.1370 & 0.0462 \\
\hline QC & $0.6913(327)$ & $0.2262(107)$ & $0.0825(39)$ & 473 & 0.8044 & 0.1956 & $37.3531 *$ \\
\hline Total & $0.7099(553)$ & $0.2169(169)$ & $0.0732(57)$ & 779 & 0.8184 & 0.1816 & $56.9060 *$ \\
\hline
\end{tabular}

$\mathrm{HW}=$ Hardy-Weinberg equilibrium; $\mathrm{LX}=\mathrm{Luxi} ; \mathrm{SL}=$ Simmental and Luxi crossbred steers; $\mathrm{NY}=$ Nanyang; $\mathrm{XN}=$ Xia'nan; JR = Jiaxian red; QC $=$ Qinchuan. $* \mathrm{P}<0.05$.

Table 3. Genetic diversity of the bovine $M y o G$ gene exon 1.
\begin{tabular}{lcccc}
\hline Breed & Homozygosity & Heterozygosity & Effective allele number & PIC \\
\hline LX & 0.7188 & 0.2812 & 1.3912 & 0.2417 \\
SL & 0.7848 & 0.2152 & 1.2742 & 0.1920 \\
NY & 0.6843 & 0.3175 & 1.4652 & 0.2671 \\
XN & 0.7059 & 0.2941 & 1.4165 & 0.2508 \\
JR & 0.7636 & 0.2364 & 1.3097 & 0.2085 \\
QC & 0.6854 & 0.3146 & 1.4591 & 0.2651 \\
Total & 0.7027 & 0.2973 & 1.4231 & 0.2531 \\
\hline
\end{tabular}

$\mathrm{PIC}=$ polymorphism information content. For breed abbreviations, see legend to Table 2.

\section{Effect of the $M y o G$ gene genotypes on body measurement traits}

Eight body measurement traits were analyzed by the comparison between the genotypes of 779 individuals and their phenotypic data. The results of association analysis of the gene-specific SNP marker are shown in Table 4. Least squares analysis revealed a significant $(\mathrm{P}<0.05)$ association of the $M y o G$ SNP with rump length in four breeds (LX, XN, JR, and QC), with hucklebone width in three breeds (SL, NY and XN), with waist height in two breeds 
(SL and NY) and with body length in the LX breed. No significant correlations were observed between any of the marker genotypes at T314C and other traits (data not shown).

Table 4. Associations of bovine $M y o G$ gene exon 1 genotypes with body measurement traits.

\begin{tabular}{|c|c|c|c|c|c|}
\hline \multirow[t]{2}{*}{ Breed } & \multirow[t]{2}{*}{ Genotype } & \multicolumn{4}{|c|}{ Body measurement traits } \\
\hline & & Body length & Waist height & Rump length & Hucklebone width \\
\hline \multirow[t]{3}{*}{ LX } & TT & $139.594 \pm 1.628^{\mathrm{a}}$ & $131.219 \pm 0.948$ & $44.375 \pm 0.854^{\mathrm{a}}$ & $21.531 \pm 0.312$ \\
\hline & $\mathrm{TC}$ & $132.857 \pm 3.255^{\mathrm{ab}}$ & $128.500 \pm 1.896$ & $42.625 \pm 1.707^{\mathrm{ab}}$ & $20.875 \pm 0.624$ \\
\hline & $\mathrm{CC}$ & $126.000 \pm 6.511^{\mathrm{b}}$ & $125.500 \pm 3.793$ & $37.000 \pm 3.414^{\mathrm{b}}$ & $20.500 \pm 1.247$ \\
\hline \multirow[t]{3}{*}{ SL } & TT & $129.286 \pm 0.923$ & $124.119 \pm 0.683^{\mathrm{a}}$ & $39.405 \pm 0.509$ & $21.214 \pm 0.408^{\mathrm{a}}$ \\
\hline & $\mathrm{TC}$ & $126.889 \pm 1.993$ & $123.667 \pm 1.476^{\mathrm{a}}$ & $39.667 \pm 1.100$ & $20.778 \pm 0.881^{\mathrm{ab}}$ \\
\hline & $\mathrm{CC}$ & $124.500 \pm 4.228$ & $117.000 \pm 3.131^{\mathrm{b}}$ & $39.000 \pm 2.333$ & $17.500 \pm 1.868^{\mathrm{b}}$ \\
\hline \multirow[t]{3}{*}{ NY } & TT & $151.281 \pm 1.054$ & $131.031 \pm 0.769^{\mathrm{a}}$ & $40.469 \pm 0.537$ & $27.922 \pm 0.370^{\mathrm{a}}$ \\
\hline & $\mathrm{TC}$ & $149.100 \pm 1.885$ & $127.900 \pm 1.376^{\mathrm{ab}}$ & $39.400 \pm 0.960$ & $26.900 \pm 0.662^{\mathrm{ab}}$ \\
\hline & $\mathrm{CC}$ & $146.800 \pm 2.666$ & $126.600 \pm 1.946^{\mathrm{b}}$ & $38.600 \pm 1.358$ & $25.800 \pm 0.936^{\mathrm{b}}$ \\
\hline \multirow[t]{3}{*}{$\mathrm{XN}$} & TT & $153.687 \pm 2.953$ & $137.500 \pm 1.294$ & $49.375 \pm 1.012^{\mathrm{a}}$ & $25.281 \pm 0.691^{\mathrm{a}}$ \\
\hline & $\mathrm{TC}$ & $143.200 \pm 5.283$ & $136.000 \pm 2.315$ & $48.000 \pm 1.810^{\mathrm{ab}}$ & $23.000 \pm 1.237^{\mathrm{ab}}$ \\
\hline & $\mathrm{CC}$ & $138.500 \pm 8.353$ & $135.000 \pm 3.661$ & $42.000 \pm 2.862^{\mathrm{b}}$ & $20.000 \pm 1.956^{\mathrm{b}}$ \\
\hline \multirow[t]{3}{*}{$J R$} & TT & $130.151 \pm 1.308$ & $123.792 \pm 0.714$ & $42.906 \pm 0.416^{\mathrm{a}}$ & $21.170 \pm 0.405$ \\
\hline & $\mathrm{TC}$ & $126.733 \pm 2.458$ & $123.733 \pm 1.343$ & $40.800 \pm 0.781^{\mathrm{ab}}$ & $21.000 \pm 0.761$ \\
\hline & $\mathrm{CC}$ & $121.500 \pm 6.733$ & $122.000 \pm 3.677$ & $38.500 \pm 2.140^{\mathrm{b}}$ & $20.000 \pm 2.083$ \\
\hline \multirow[t]{3}{*}{ QC } & TT & $127.908 \pm 1.407$ & $123.939 \pm 1.139^{\mathrm{a}}$ & $42.051 \pm 0.574^{\mathrm{a}}$ & $23.786 \pm 0.682$ \\
\hline & $\mathrm{TC}$ & $123.824 \pm 2.390$ & $121.853 \pm 1.933^{\mathrm{ab}}$ & $41.588 \pm 0.974^{\mathrm{ab}}$ & $22.824 \pm 1.157$ \\
\hline & $\mathrm{CC}$ & $119.667 \pm 4.022$ & $115.667 \pm 3.254^{\mathrm{b}}$ & $38.500 \pm 1.640^{\mathrm{b}}$ & $22.667 \pm 1.948$ \\
\hline
\end{tabular}

Data are reported as measn $\pm \mathrm{SE}$ in $\mathrm{cm}$. ${ }^{\mathrm{a}, \mathrm{b}}$ Different superscript letters in the same column indicate significant difference $(\mathrm{P}<0.05)$. For breed abbreviations, see legend to Table 2.

\section{DISCUSSION}

As we have pointed out, the $M y o G$ gene has a crucial role during myogenesis. Studies on polymorphisms of the $M y o G$ gene have been conducted in pigs and goats. PCRRFLP analysis using NlaIV revealed that the $M y o G$ gene existed as at least in two different restricted nuclease polymorphic fragments (Mendez et al., 1997). Southern blot analysis of 105 unrelated pigs revealed that there were three polymorphic MspI sites (Soumillion et al., 1997; te Pas et al., 1999). The significant effect of the $M y o G$ gene on birth weight, growth rate and lean weight has been detected by te Pas et al. (1999). These results have been further confirmed by SNP studies of the $M y o G$ gene (Kapelanski et al., 2005; Wyszynska-Koko et al., 2006; Verner et al., 2007). Bhuiyan et al. (2009) detected a $\mathrm{G}>\mathrm{C}$ mutation in exon 1 among six breeds, including Hanwoo, Angus, Simmental, Hereford, Shorthorn, Brahman, and Red Chittagong.

Therefore, considering the evolutionary conservation among cattle, pigs and goats, we applied the results of the research cited above to determine the polymorphism and genetic effect of the cattle $M y o G$ gene exon 1. In this study, the possible relationship between the $M y o G$ polymorphism and body measurement traits was evaluated by using blood samples from 779 cattle belonging to six different cattle populations. The frequencies of the $\mathrm{CC}$ genotype were low in the six native Chinese cattle. The possibility of this observation is the occurrence of gene drift due to the low frequency of allele C. Among the six populations included in the study, comparison of body measurement traits between individuals with the TT genotype revealed significant effects on rump length, hucklebone width, waist height, and body length ( $\mathrm{P}$ $<0.05$ ). Individuals with genotype TT had superior body measurement traits, which indicates 
that allele $\mathrm{T}$ may be the beneficial allele for body measurement traits in the native Chinese breed types. Allele $\mathrm{C}$ could be a recent mutation, where the presence of the $\mathrm{C}$ allele in the homozygote individuals significantly decreases their body measurement traits $(\mathrm{P}<0.05)$.

$M y o G$ is expressed in all myoblasts from the start of differentiation, and its expression continues during cell fusion. MyoG expression also marks the end of the proliferation of myoblasts. Thus, when $M y o G$ is expressed, muscle fibers develop from the myoblasts that were previously formed. Therefore, different $M y o G$ function or timing of expression could have a major influence on the number of muscle fibers that develop during myogenesis. $M y o G$ knock-out mice show no muscle fiber development, and heterozygous $M y o G$ knock-out mice show half the number of muscle fibers of wild-type mice (Hasty et al., 1993).

The novel SNP (T314C) could result in a synonymous mutation in the $M y o G$ protein. The degeneracy of the genetic code enables the same amino acid sequences to be encoded and translated in many different ways (Komar, 2007). We know that the genome is highly redundant in terms of tRNA species for each amino acid but enigmatically underrepresents a number of specific codons (Shah et al., 2008). Thus, in the synthesis of the MyoG protein, if the base change at the third position of the codon is not represented by a corresponding anti-codon within the nuclear tRNA, the rate of expression of the $M y o G$ protein could change. Therefore, we hypothesize that naturally occurring genetic variation in $M y o G$ could affect muscle fiber numbers and, thus, body measurement.

In conclusion, we identified an SNP in the $M y o G$ gene and investigated its relevance in six native Chinese cattle. Our results provide evidence that the $M y o G$ gene may have potential effects on body measurement traits in native Chinese cattle. Therefore, further studies are necessary before using this SNP for marker-assisted selection in larger populations. It is also important to determine whether the $M y o G$ gene plays a role in the development of those traits and whether it is involved in linkage disequilibrium with other causative mutations.

\section{ACKNOWLEDGMENTS}

Research supported by the China National 863 Program (\#2010AA10Z101, \#2008AA101010), the National Eleventh "Five Year" Science and Technology Support Project (\#2006BAD01A10-3), and GMO New Varieties Major Project (\#2008ZX08007-002). In addition, the cattle populations were supported by the Qinchuan Beef Cattle Breeding Center of Shaanxi Province, the Nanyang, Jiaxian and Xianan Cattle Breeding Center of Henan Province and the Luxi Cattle Breeding Center of Shandong Province (P.R. China).

\section{REFERENCES}

Anton I, Fésüs L and Zsolnai A (2002). Simultaneous identification of two MspI polymorphisms of the porcine myogenin gene in Hungarian breeds. J. Anim. Breed. Genet. 119: 280-283.

Bhuiyan MSA, Kim NK, Cho YM, Yoon D, et al. (2009). Identification of SNPs in MyoD gene family and their associations with carcass traits in cattle. Livest. Sci. 126: 292-297.

Braun T, Buschhausen-Denker G, Bober E, Tannich E, et al. (1989). A novel human muscle factor related to but distinct from $M y o D_{l}$ induces myogenic conversion in 10T1/2 fibroblasts. EMBO J. 8: 701-709.

Buckingham M, Bajard L, Chang T, Daubas P, et al. (2003). The formation of skeletal muscle: from somite to limb. $J$. Anat. 202: 59-68.

Casas E, Keele JW, Shackelford SD, Koohmaraie M, et al. (2004). Identification of quantitative trait loci for growth and carcass composition in cattle. Anim. Genet. 35: 2-6. 
Davis RL, Weintraub H and Lassar AB (1987). Expression of a single transfected cDNA converts fibroblasts to myoblasts. Cell 51: 987-1000.

Gilbert RP, Bailey DR and Shannon NH (1993). Linear body measurements of cattle before and after 20 years of selection for postweaning gain when fed two different diets. J. Anim. Sci. 71: 1712-1720.

Hasty P, Bradley A, Morris JH, Edmondson DG, et al. (1993). Muscle deficiency and neonatal death in mice with a targeted mutation in the myogenin gene. Nature 364: 501-506.

Kapelanski W, Grajewska S, Kuryl J, Bocian M, et al. (2005). Polymorphism in coding and non-coding regions of the MyoD gene family and meat quality in pigs. Folia Biol. 53: 45-49.

Komar AA (2007). Silent SNPs: impact on gene function and phenotype. Pharmacogenomics 8: 1075-1080.

Liu YF, Zan LS, Li K, Zhao SP, et al. (2010). A novel polymorphism of GDF5 gene and its association with body measurement traits in Bos taurus and Bos indicus breeds. Mol. Biol. Rep. 37: 429-434.

Mendez EA, Ernst CW and Rothschild MF (1997). Rapid communication: a novel DNA polymorphism of the porcine myogenin (MyoG) gene. J. Anim. Sci. 75: 1984.

Mullenbach R, Lagoda PJ and Welter C (1989). An efficient salt-chloroform extraction of DNA from blood and tissues. Trends Genet. 5: 391.

Olson EN (1990). MyoD family: a paradigm for development? Genes Dev. 4: 1454-1461.

Pas MF and Visscher AH (1994). Genetic regulation of meat production by embryonic muscle formation - a review. $J$. Anim. Breed. Genet. 111: 404-412.

Qu L, Li X, Wu G and Yang N (2005). Efficient and sensitive method of DNA silver staining in polyacrylamide gels. Electrophoresis 26: 99-101.

Rehfeldt C, Fiedler I, Dietl G and Ender K (2000). Myogenesis and postnatal skeletal muscle cell growth as influenced by selection. Livest. Prod. Sci. 66: 177-188.

Shah JH, Maguire DJ, Munce TB and Cotterill A (2008). Alanine in HI: a silent mutation cries out! Adv. Exp. Med. Biol. 614: $145-150$.

Soumillion A, Erkens JH, Lenstra JA, Rettenberger G, et al. (1997). Genetic variation in the porcine myogenin gene locus. Mamm. Genome 8: 564-568.

Stickland NC and Handel SE (1986). The numbers and types of muscle fibres in large and small breeds of pigs. J. Anat. 147: 181-189.

te Pas MF, Soumillion A, Harders FL, Verburg FJ, et al. (1999). Influences of myogenin genotypes on birth weight, growth rate, carcass weight, backfat thickness, and lean weight of pigs. J. Anim. Sci. 77: 2352-2356.

te Pas MF, Verburg FJ, Gerritsen CL and de Greef KH (2000). Messenger ribonucleic acid expression of the MyoD gene family in muscle tissue at slaughter in relation to selection for porcine growth rate. J. Anim. Sci. 78: 69-77.

Verner J, Humpolicek P and Knoll A (2007). Impact of MyoD family genes on pork traits in Large White and Landrace pigs. J. Anim. Breed. Genet. 124: 81-85.

Weintraub H, Tapscott SJ, Davis RL, Thayer MJ, et al. (1989). Activation of muscle-specific genes in pigment, nerve, fat, liver, and fibroblast cell lines by forced expression of MyoD. Proc. Natl. Acad. Sci. U. S. A. 86: 5434-5438.

Weintraub H, Davis R, Tapscott S, Thayer M, et al. (1991). The MyoD gene family: nodal point during specification of the muscle cell lineage. Science 251: 761-766.

Wright WE, Sassoon DA and Lin VK (1989). Myogenin, a factor regulating myogenesis, has a domain homologous to MyoD. Cell 56: 607-617.

Wyszynska-Koko J, Pierzchala M, Flisikowski K, Kamyczek M, et al. (2006). Polymorphisms in coding and regulatory regions of the porcine MYF6 and MYOG genes and expression of the MYF6 gene in $\mathrm{m}$. longissimus dorsi versus productive traits in pigs. J. Appl. Genet. 47: 131-138.

Zhang C, Wang Y, Chen H, Lan X, et al. (2007). Enhance the efficiency of single-strand conformation polymorphism analysis by short polyacrylamide gel and modified silver staining. Anal. Biochem. 365: 286-287. 